\title{
Baklagillerde Kök, Nodül Oluşumu ve Azot Fiksasyonu Üzerine Bazı Küresel İklim Değişikliği Parametrelerinin Etkisi
}

\author{
İlkay Yavaş ${ }^{1 *} \quad$ Aydın Ünay² \\ ${ }^{1}$ Aydın Adnan Menderes Üniversitesi, Koçarlı Meslek Yüksekokulu, Bitkisel ve Hayvansal Üretim Bölümü, Aydın \\ ${ }^{2}$ Aydın Adnan Menderes Üniversitesi, Ziraat Fakültesi, Tarla Bitkileri Bölümü, Aydın
}

Geliş tarihi (Received): 15.12.2017 Kabul tarihi (Accepted): 09.03.2018

\begin{abstract}
Anahtar kelimeler:
Özet. Küresel iklim değişikliği sürecinde atmosferdeki karbondioksit ve sıcaklıktaki artışın kuraklık ve Baklagiller, $\mathrm{CO}_{2}$ artışı, kuraklık, sıcaklık, tuzluluk tuzluluğu artıracağı bir gerçektir. Bu değişikliklerin özellikle kurak ve yarı-kurak iklimlerde yetiştirilen baklagilleri olumsuz yönde etkileyeceği bildirilmiştir. Bu derlemede özellikle bu olumsuzlukların köknodül oluşumu ve biyolojik azot özümlemesi (BNF) üzerine olan etkileri tartışılmıştır. Baklagiller ve bakteriler arasındaki simbiyotik ilişki artan $\mathrm{CO}_{2}$ koşulları ile birlikte artışı nodül gelişimini hızlandırmış

*Sorumlu yazar iyavas@adu.edu.tr ve BNF artışı görülmüştür. Buna karşın iklim senaryolarına göre $2-4{ }^{\circ} \mathrm{C}$ sıcaklık artışı ve beraberinde kuraklığın kök tüyü infeksiyonunu, nodül sayısını, nodül büyüklüğünü, nodül gelişimini ve aktivitesini azaltarak BNF'yi olumsuz etkilediği saptanmıştır. Öte yandan tuzluluğun nodül solunumunu ve leghemoglobin içeriğini azalttığı vurgulanmıştır.
\end{abstract}

\section{Impact of Some Climate Change Parameters on Root, Nodule Formation and Nitrogen Fixation in Legumes}

\footnotetext{
Keywords: Legumes, elevated $\mathrm{CO}_{2}$ drought, temperature, salinity

\begin{abstract}
In the context of global climate change, the increase in carbon dioxide and temperature in the atmosphere is a fact that will increase drought and salinity. These changes have been reported to adversely affect legumes grown especially in arid and semi-arid climates. In this review, the effects of these adverse events on root-nodule formation and biological nitrogen fixation (BNF) are discussed. The symbiotic relationship between legumes and bacteria, together with increased $\mathrm{CO}_{2}$ conditions, accelerated nodule development and increased BNF. However, according to climate scenarios, temperature increases of $2-4{ }^{\circ} \mathrm{C}$ with accompanying drought, decreased root hair infection, nodule number, nodule size, nodule growth and activity and BNF was found to be adversely affected. On the other hand, it was emphasized that salinity reduced nodule respiration and leghemoglobin content.
\end{abstract}


Yavaş ve Ünay, Baklagillerde Kök, Nodül Oluşumu ve Azot Fiksasyonu Üzerine Bazı Küresel İklim Değişikliği Parametrelerinin Etkisi

\section{GíRiş}

Baklagiller başta protein olmak üzere karbonhidrat ve yağ içeriği ile insan ve hayvanlar için önemli besin kaynaklarıdır. Biyolojik azot özümlemesi (BNF) ise baklagilleri ekim nöbeti içerisinde vazgeçilmez kılmaktadır. Dane bileşimlerinin yanında yeşil aksamlarının da protein içeriğinin yüksek olması yeşil gübre ve örtü bitkisi olanaklarını artırmaktadır. Bu etkileri nedeniyle toprağın fiziksel koşullarını da iyileştirerek, daha iyi strüktür yapı sağlamakta, daha iyi su tutma kapasitesine ve havalanmaya neden olmaktadırlar (Prasad et al., 2005). Dünyada baklagil üretimi tahıl ve yağlı tohumlardan sonra üçüncü sırada gelmektedir ve toplam üretimin \%27'sini oluşturmaktadır (Graham and Vance 2013). Baklagiller gerçekleştirdikleri BNF nedeniyle, toprak verimliliğini artırmakta ve azotlu gübrelere bağımlıı̆̆ı azaltmaktadır. Baklagil bitkilerinin kullanımı ile azotlu gübre kullanımı sonucu meydana gelecek çevresel ve sosyo-ekonomik tehlikeler de en aza indirilmektedir.

Atmosferde $\mathrm{CO}_{2}$ konsantrasyonunda, ortam sıcaklığında ve kurak dönemlerde meydana gelen artış küresel değişim sürecinin bilinen sonuçları içerisinde yer almaktadır (Feller 2016). IPCC (2013) rapor sonuçları, karbondioksit $\left(\mathrm{CO}_{2}\right)$ ve metan $\left(\mathrm{CH}_{4}\right)$ gazlarının 2011 yılı konsantrasyonlarının sanayi öncesi düzeylerine göre sırasıyla 391 ppm ve 1803 ppb düzeylerine yükseldiğini göstermiştir. Bu sera gazı konsantrasyonundaki artışın 1986-2005 dönemine göre ortam sıcaklığını 2016-2035 döneminde büyük olasılıkla $0.3-0.7^{\circ} \mathrm{C}$ artıracağı öngörülmektedir.

Artan sıcaklık, evapotranspirasyon oranını artıracak ve su miktarındaki düşüşü şiddetlendirecektir. Yıllık evapotranspirasyon oranı yağış miktarının neredeyse iki katı olan Akdeniz Bölgesi gibi yerlerde tuzluluk problemleri yaygın bir şekilde gözlenecektir. Akdeniz iklim koşullarında su eksikliği; toprak $N$ içeriği ve tuzluluk ile birlikte bitki büyümesini ve üretimini sınırlayan en önemli çevresel faktör olması nedeniyle önemli bir problemdir. Son 40 yılda, bitkilere uygulanan sentetik azot (N) miktarı, 12.000.000104.000.000 ton/yıl olacak şekilde önemli derecede artmış; bu durum verimde önemli yükselişler meydana getirmiş fakat dünya genelinde çevre üzerinde olumsuz etkiler ortaya koymuştur. Aşırı gübreleme nedeniyle azotun çevre üzerindeki etkileri gittikçe belirginleşmektedir. Tane baklagiller tarımsal ekosistemlerde simbiyotik azot fiksasyonunda önemli rol oynayan önemli protein kaynağıdırlar (Farooq et. al., 2016). Biyolojik azot fiksasyonu baklagiller ve çevredeki bitkilere, fakir topraklara ilave bir azot kaynağı sağlamaktadır. Bu simbiyotik ilişki, karasal ekosistemlerde azot fiksasyonunun ana kaynağını oluşturmakta ve kimyasal bileşiklerle toprakları gübreleme intiyacını azaltarak çevresel ve ekonomik yönden yarar sağlamaktadır. Biyotik stresin (hastalık, zararlı, yabancı ot) ya da abiyotik stresin (sıcaklık, su, besin elementi) olmadığı durumlarda artan $\mathrm{CO}_{2}$ koşulları büyüme ve fotosentezdeki artış nedeniyle artacaktır. Verim ve verim bileşenleri üzerine artan $\mathrm{CO}_{2}$ 'in yararlı etkisi, yüksek sıcaklığın negatif etkilerinden daha fazladır (Prasad et al., 2005).

Baklagillerde kök gelişimini, nodül oluşumunu ve azot fiksasyonunu etkileyen faktörler aşağıda kısaca belirtilmiştir.

\section{Sicaklık}

Küresel iklim değişikliği dünyanın farklı bölgelerinde ekstrem sıcaklık (yüksek veya düşük) olayları ile sonuçlanmaktadır (Bhandari et al., 2017). Sıcaklık; bitkinin yetişme koşullarını belirleyen en önemli çevre faktörlerinden birisi olup, bitki fenolojisi ve verimini etkilemektedir. Çeşitli biyotik ve abiyotik faktörler baklagillerde üretim potansiyelini sınırlamakla birlikte, sıcaklık stresi bu potansiyeli olumsuz yönde etkileyen faktörlerin en önemlilerinden birisidir.

Aranjuelo et al. (2014)'e göre nodül ve bakteroid oluşumları sıcaklık artışlarına bitkinin diğer kısımlarına kıyasla daha hassastır. Düşük fotosentez oranlarına rağmen, yüksek sıcaklıklara maruz kalma yaprakta çözünmüş şeker içeriğini azaltmış fakat nodül seviyesinde önemli bir fark gözlenmemiştir. Artan sıcaklıklar nodül malat dehidrogenaz (MDH) aktivitesini bakteroid seviyesinde \%50'ye kadar azaltmıştır. Yüksek sıcaklıkların glutamin sentetaz ve glutamat sentetaz gibi amino asit biyosentezinde rol oynayan enzimleri olumsuz etkilediği ve üreidlerin sentezini azalttığı ortaya çıkmıştır.

Bitkilerin maksimum ve minimum sıcaklık eşiği farklıdır. Yüksek sıcaklıklar (sıcaklık stresi) ve düşük sıcaklıklar (soğuk stresi) bitki gelişim dönemlerinde zarara yol açarak ciddi verim kayıplarına neden olmaktadır. Bazı bakteri ırklarının azot fiksasyon yeteneği sıcaklık gibi çeşitli olumsuz koşullara hassastır. Optimum sıcaklık seviyesinin altındaki sıcaklıklar, kök infeksiyonunu uzatmakta nodül gelişimi ve nitrogenaz aktivitesini engellemektedir. Rhizobium bakterilerinin sıcaklık hassasiyeti baklagillerde azot fiksasyonunu doğrudan etkilemektedir. Sıcaklıkların $10{ }^{\circ} \mathrm{C}$ 'nin altına düşmesi zayıf nodülasyon oluşumu ve rhizobial gelişime neden olmuş, fakat bazı Rhizobium ve Bradirhizobium ırklarının düşük sıcaklıklara adapte olmasına neden olmuştur (Bhandari et al., 2017). 

Etkisi

Çiçeklenme öncesi meydana gelen sıcaklık stresi, erken çiçeklenmeye yol açmış ve azot fiksasyon etkinliğini etkileyen nodüllerin dejenere olmasına yol açmıştır (Gaur et al., 2015).

Yapılan bir çalışmada; yüksek sıcaklık stresine (35$38^{\circ} \mathrm{C}$, 8 saat gün ${ }^{-1}$ ) maruz bırakılan fasulye bitkisinde nodül oluşumu gözlenmesine rağmen, azot fiksasyonunun yetersiz kaldığı belirlenmiştir. Bitkiler çiçeklenme döneminde yüksek sıcaklıklara $\left(40{ }^{\circ} \mathrm{C}, 8\right.$ saat gün-1) maruz kaldığında, nitrogenaz aktivitesi önemli bir şekilde azalmış, bu nedenle azot fiksasyonu da gerilemiştir (Hungria et al., 1993).

Yüksek sıcaklıklar nodül oluşumunu azaltmakta, nodül fonksiyonuna zarar vermekte ve nodül yapısını etkilemektedir. Nohutta azot fiksasyon etkinliği ve nodül oluşumu üzerine sıcaklığın zararlı etkisi devam eden $30{ }^{\circ} \mathrm{C}$ gündüz/18 ${ }^{\circ} \mathrm{C}$ gece sıcaklıklarında gözlenmiştir (Minchin et al., 1980). Gündüz sıcaklıklarındaki artış $\left(32.5{ }^{\circ} \mathrm{C}\right)$ nohut bitkisinde nodülasyonu geciktirmiş, toplam azot fiksasyonu ve simbiyotik olarak aktif nodül popülasyon ömrü azalmıştır (Rawsthorne et al., 1985). Nodüller $32{ }^{\circ} \mathrm{C}$ 'nin üzerindeki sıcaklıklarda oluşmamış, nohut köklerinin $35^{\circ} \mathrm{C}$ ye maruz kalması nitrogenaz aktivitesinde geri dönüşümü olmayan sonuçlar ortaya koymuştur (Dart et al., 1975).

Rhizobium-baklagil birlikteliği yüksek toprak sıcaklıklarında gelişimi, Rhizobiumların hayatta kalmasını, kök tüyleri oluşumunu, infeksiyon iplikçiği oluşumunu, kök nodüllerinin yapısal gelişimini, nitrogenaz enzim aktivitesini etkileyerek nodül sayısını ve nodül çapını azaltmıştır (Prasad et al., 2005).

\section{Kuraklık}

Dünyanın birçok bölgesinde baklagil üretimi kuraklıktan olumsuz bir şekilde etkilenmektedir. Kuraklık veya tuzluluk gibi bazı çevresel koşullar, nodüllerin yaşlanmasına ve $\mathrm{O}_{2}$ dengesizliğine neden olmaktadır. Oksijen geçirgenliğindeki azalma, bakteroid için oksijenin sınırlanmasına yol açmaktadır. $\mathrm{O}_{2}$ kontrolündeki dengesizlik, hücre hasarına yol açabilen Reaktif oksijen türleri (ROS) oluşumu ile ilişkilidir. Kurak koşullar baklagillerin nodülasyonunu ve infeksiyonunu azaltarak morfolojik değişikliklere yol açmaktadır. Soyada yapılan bir çalışmada kuraklığın nodül çapını azalttığı ve soya nodüllerinde lentisellerin kayıplarına neden olduğu anlaşılmıştır. Baklada düşük toprak nemi, infeksiyon iplikçiği sayısını önemli bir şekilde azaltmıştır. Kuraklığa maruz kalan bakla bitkilerinde dış kortikal hücrelerde deformasyon ortaya çıkmıştır. Kuraklık ayrıca daha düşük nitrogenaz aktivitesine yol açarak kök bakteroidlerine dayanıkıııkta oksijen difüzyonunu artırarak simbiyotik azot fiksasyonunu etkilemiştir. Bu da tane baklagiller için önemli olup, protein biyosentezi için daha düşük azot ile sonuçlanmakta ve tane verimini azaltmaktadır (Farooq et al., 2016).

Kunert et al. (2016)'nın bildirdiğine göre; kurak koşullar altında soya bitkisinde kök uzunluğu ve biyomas birikimi azalmıştır. Kuraklık sadece kök yapısında (kök derinliği, kök dallanma yoğunluğu ve kök açısı) değişikliğe yol açmamış ayrıca kök kütlesindeki artış ile kök ve sürgün biyoması da değişmiştir. Soya bitkisi şiddetli kuraklık koşullarına maruz kaldığında nodül sayısı da azalmıştır. Nodüllerin kuraklık toleransı, daha fazla nodül biyoması oluşturma ve kuraklık süresince nodüllere fotosentez ürünleri sağlamayı sürdürme yeteneği ile ilişkilidir. Şiddetli kuraklığa maruz kalma durumu nitrogenaz aktivitesini zayıflatmaktadır. Bu durum simbiyotik azot fiksasyonu için nodüllere fotosentez ürünlerinin sağlanmasının azalmasından ve oksijen difüzyon bariyerinin yıkılması ya da leghemoglobin kaybını da içeren bazı faktörlerden kaynaklanabilmektedir.

Su stresi koşullarında, fotosentez aktivitesi azalmakta veya engellenmekte, nitrogenaz aktivitesinde düşüş ile birlikte bakteroidlere karbonhidrat temini azalmaktadır. Bu durum nodüllerde sükrozun parçalanmasından sorumlu enzimlere (sükroz sentaz (SuSy)) bağlı olabilmektedir. Nitrogenaz aktivitesindeki azalma azotlu bileşiklerin birikimi ile ilişkilendirilmektedir. Bu bileşiklerin birikimi, nodüldeki karbonhidrat miktarının düşmesi ya da ksilemde taşınmada bozulma ya da azotlu bileşiklerin bitkiye taşınımının azalmasından kaynaklanabilmektedir. Bu bileşiklerin birikimi, nitrogenaz aktivitesinin engellenmesi sonucu negatif bir geri besleme mekanizmasına neden olmaktadır. Ayrıca, azot birikimi, azot isteğinin azalmasından kaynaklanabilmekte ve nitrogenaz aktivitesinin engellenmesi sonucu nodüllerde $\mathrm{N}_{2}$ fiksasyon ürünlerinin birikmesine neden olabilmektedir. Su stresi koşulları $\mathrm{O}_{2}$ difüzyon geçirgenliğinde ve nodül solunumunda azalmaya dolayısıyla ATP sentaz yoluyla düşük enerji üretimine neden olmaktadır (Aranjuelo et al., 2014).

Çöl topraklarında Rhizobium oluşumu ve baklagillerde etkili nodülasyon, Rhizobiumların kısıtlı su koşullarında da toprakta oluştuğunu göstermiştir. Fakat popülasyon yoğunluğu kurak koşullarda düşük olma eğilimindedir. Bazı serbest yaşayan Rhizobiumlar (saprofitik) kuraklık stresi ya da düşük su içeriğinde hayatta kalma yeteneğindedirler. Rhizobiumların su stresine (düşük nem içeriğine) en erken tepkilerinden birisi morfolojik değişiklikler ile ilişkilidir. $T$. subterraneum ile yapılan bir çalışmada; toprak 
nemindeki düşüş infeksiyon iplikçikleri sayısını önemli bir şekilde azaltmış ve nodül oluşumunu tamamen engellemiştir (Worrall and Roughley 1976). Yine soya ile yapılan bir başka çalışmada; orta derecede su stresinin soya köklerinde nodül sayısını azalttığı, orta ve şiddetli derecede su stresinin ise nodül boyutunu küçülttüğü bildirilmiştir (Williams and De Mallorca 1984). Baklagillerde simbiyotik $\mathrm{N}_{2}$ fiksasyonu toprakta nem eksikliğine oldukça hassastır. Medicago sativa, Pisum sativum, Arachis hypogea, Vicia faba, Glycine max, Vigna sp., Aeschynomene ve Adenocarpus gibi baklagillerde toprakta nem eksikliği durumunda azot fiksasyonunda azalma gözlenmiştir (Zahran 1999). Toprakta nem eksikliğine karşı nodül oluşumu, gelişimi ve aktivitesi, kök ve sürgün metabolizmasına kıyasla daha duyarlıdır. Su stresine karşı nodül oluşumu ve azot fiksasyonunun tepkisi bitki büyüme dönemine bağlı olarak değişmektedir. Vejetatif gelişme döneminde meydana gelen su stresi nodül oluşumu ve azot fiksasyonu üzerinde generatif döneme kıyasla daha zararlıdır. Su stresine duyarlılık Rhizobium ırkının çeşidine bağlı olarak değişmektedir. Su stresinin bazı baklagil yem bitkilerinde örneğin $M$. sativa ve tane baklagillerde örneğin Arachis hypogea ve bazı tropik bölge baklagillerinde de örneğin Desmodium intortum'da azot fiksasyonu üzerinde hiçbir etkiye sahip olmadığı ya da çok az etkisinin olduğu gözlenmiştir. Organik çözeltilerin birikimi devam eden ve şiddetli su stresine maruz kalan bitkilerin belirgin bir tepkisidir. Glycine max ve Phaseolus vulgaris gibi farklı baklagillerde bu çözeltilerden birisi de prolindir. Bu bitkilerde prolin birikimi ve kuraklık toleransı arasında pozitif bir ilişki bulunmaktadır. Diğer bileşikler örneğin serbest aminoasitler ve diğer düşük moleküler ağırlığa sahip çözeltiler örneğin pinitol, kuraklık stresinde çeşitli baklagillerde gözlenmiştir (Zahran 1999).

Toprakta nem eksikliği, $N_{2}$ fiksasyonu üzerinde belirgin bir etkiye sahiptir. Çoğu durumda, suyun tutulmasından 3 gün sonra nitrogenaz aktivitesi azalmaya başlamış ve bu düşüş gün geçtikçe daha belirgin hale gelmiştir. Su stresi altında, yaprak seviyesinde Rubisco'nun bozulması ve stomaların kapanması nedeniyle fotosentez engellenmiştir. Bu durum malat şeklinde sükroz birikimine ve organik asitlerin azalmasına neden olmuştur. Bu da bakteroid solunumu için substrat sıkıntısına yol açmıştır. Sonuç olarak, enfekte bölgede geçici bir oksijen birikimi meydana gelmiş ve nitrojenaz hasarını önlemek için oksijen difüzyon bariyerinin direncinde artış gözlenmiştir. Hem solunum substratlarının tüketilmesi hem de oksijen difüzyon bariyerinin kapatılması, BNF'da düşüşe neden olmuştur. Erken kuraklık koşullarında azotlu bileşiklerde artış gözlenmiştir.
Ayrıca nodülde osmotik düzenleyici etkinliğe sahip çözünür şekerler (sükroz, rafinoz), şeker alkolleri (galaktinol, miyo-inositol, pinitol) ve organik asitlerde (fumarik asit, malat) artışa neden olduğu ortaya çıkmıştır. Organik çözeltilerin birikimi su stresi koşullarında turgorun onarımı, serbest radikallerin yol açtığı oksidatif hasarın azaltılması, membran yapısı ve enzimlerin stabilizasyonunu içermektedir. Belli organik çözeltilerin (ozmotik) birikimi, uzun süreli şiddetli su stresine maruz kalan bitkilerin karakteristik bir tepkisidir. Bu anlamda, bitkiler, nodül ve yaprak su durumunu stabilize etmek için belirgin miktarda karbonhidrat yönlendirmektedir. M. sativa'da kuraklığa maruz kalan nodüllerde çözünür şeker ve organik asit birikimi gözlenmiştir. Bu birikim nodüllerdeki karbonhidratların mobilizasyonundan kaynaklanmıştır. Ağır kuraklık koşullarında, solunumda ki düşüş, sitosolik leghomoglobin içeriğindeki artış, katalitik Fe'nin zenginliği ve redoks proteinlerinin varlığı ROS içeriğini düzenlemenin önemini ortaya koymuştur. Bununla birlikte şiddetli su stresinin antioksidan aktivitesinde düşüşe neden olduğu gözlenmiştir. Yaprak azot içeriği, toplam çözünebilir proteinler (TSP) ve Rubisco içeriği düşük su içeriğinden olumsuz etkilenmiştir. Daha düşük sürgün $N$ isteği, nodül TSP içeriğini ve $\mathrm{N}_{2}$ asimilasyonunda rol oynayan malat dehidrojenaz (MDH) ve aspartat aminotransferaz (AAT) gibi enzimlerin aktivitesini olumsuz yönde etkilemiştir. MDH'nin daha düşük olması, nodüllerde malatın bulunabilirliğini azaltmıştır. Kurak koşullarda bitkilerin nodül kuru madde üretimindeki fotoasimilatların daha düşük olması, bitki düzeyinde düşük $\mathrm{N}_{2}$ fiksasyonuna neden olmuştur. Şiddetli kuraklık koşullarında ise nodüllerdeki oksidatif stres ve azotlu bileşiklerin birikimi zayıf nodül oluşumuna neden olmuştur. Orta ve şiddetli stres koşullarında bitkiler, ozmoregülatör ve antioksidan bileşikler meydana getirmiştir. M. sativa, $P$. vulgaris, $P$. sativum ve soya fasulyesi gibi $\mathrm{N}$-fiksasyon bitkilerinin, azotu indirgeyen bitkilere göre kuraklığa daha toleranslı olduğu gözlenmiştir (Aranjuelo et al., 2014).

Kuraklık stresine maruz kalan soya bitkilerinin yaprak saplarında üreid miktarı artmış, azot fiksasyonu ve transpirasyon oranı ise düşmüştür. Bu nedenle üreid miktarı transpirasyon oranı ve nodül aktivitesi için bir belirleyici faktör olmuştur (De Silva et al., 1996). Kuraklık stresine maruz bırakılan Phaseolus vulgaris ve Sesbania aculeata bitkilerinde yaprak ve nodüllerde nitrat redüktaz aktivitesi azalmış fakat tuza toleranslı olan Sesbania aculeata bitkisinin kuraklığa da daha toleranslı olduğu gözlenmiştir. Ayrıca kuraklığa tolerans nodülde glisin betain içeriği, prolin ve nitrat redüktaz aktivitesinin yüksek olması ile 
Yavaş ve Ünay, Baklagillerde Kök, Nodül Oluşumu ve Azot Fiksasyonu Üzerine Bazı Küresel İklim Değişikliği Parametrelerinin Etkisi

ilişkilendirilmiştir (Ashraf and Iram 2005).

Nodül tipolojisindeki çeşitlilik bazı baklagillerin daha yüksek azot fiksasyonundan sorumludur. Örneğin bakla ve yer fıstığındaki gibi endodermiste oluşan (sınırsız) nodüller, börülce, siyah mercimek ve yeşil mercimekteki yüzeysel olarak tutunan (sınırlı) nodüllerden su stresine daha iyi karşı koyma yeteneğindedirler (Subbarao et al., 1995). Sınırsız büyüme durumunda olan nodüller olumsuz koşullar sonrasında hızlı bir şekilde büyüyebilirken, sınırlı büyümeye sahip olan nodüller kısa ömürlü olup, bitki gelişimi süresince bu ortamdan uzaklaştırımalıdır.

\section{Tuzluluk}

Tuzluluk, su veya toprakta çözünmüş mineral tuzların konsantrasyonundan ileri gelmektedir. Baklagiller tuzluluğa oldukça hassas bitkilerdir. Rhizobium bakterileri ise kendi konukçularına göre tuza daha toleranslıdır. Bazı Rhizobium bakterilerinin gelişiminin $100 \mathrm{mM} \mathrm{NaCl}$ ortamında engellendiği, $R$. meliloti'nin 300-700 mM NaCl uygulamasına toleranslı olduğu gözlenmiştir. Kök çevresinde $\mathrm{Na}^{+}$ve $\mathrm{Cl}^{-}$ iyonlarının yüksek oranda bulunması ve suyun kısıtlı olduğu alanlar, kurak ve yarı kurak iklimlerde baklagillerin coğrafik alanlarını sınırlamaktadır. Genellikle tuzlu koşullar bitkileri osmotik stres ya da iyon toksisitesi olmak üzere iki şekilde etkilemektedir. Fakat baklagiller için üçüncü bir durum söz konusudur bu da Rhizobiumlar tarafından nodülasyonun azalmasıdır. Çünkü tuzluluk Rhizobiumlarda nodül oluşumunu azaltarak ya doğrudan ya da dolaylı olarak etkide bulunmaktadır (Hanumantha Rao et al., 2016). Bununla birlikte, baklagillerin tuzluluğa tepkisi büyük oranda toprak özelliklerine, büyüme dönemlerine ve baklagil türlerine bağlı olarak değişmektedir. Nodül oluşumu tuz stresine hassas olup, tuzlu koşullarda kök tüylerinin kıvrılması engellenmiş, bakteriyel kolonizasyon ve infeksiyon büyük ölçüde azalmıştır. Yüksek oranda tuzluluk ayrıca baklagillerdeki bitki büyümesini ve simbiyotik ilişkileri olumsuz etkilemiştir (Aranjuelo et al., 2014).

Nohut bitkisinde tuz uygulamaları hassas çeşitlerde nodül sayısı, nodül kuru ağırlığı ve azot fiksasyonunu azaltmış, toleranslı çeşitlerde ise tuz konsantrasyonunun artışı ile nodül oluşumu ve nodül biyomas ağırlığı teşvik edilmiştir (Garg and Singhla 2004). Yapılan bir araştırmada; tuz stresine maruz kalan Medicago ciliaris hatlarından, toleranslı olan türde bitki büyümesinin $\% 21$, hassas olanda ise $\% 73$ oranında engellendiği ve sırasıyla $\mathrm{N}_{2}$ fiksasyonunun \%60 ve \%86 oranında azaldığı gözlenmiştir. Tuza duyarlı bitkilerde (M. ciliaris), çözünebilir şeker içeriğinin (sükroz dahil) nodüllerde azaldığı ortaya çıkmıştır. Sükroz sentazı ve alkalin/nötral invertaz araştırmaları bu bitkilerin düşük sükroz içeriğinin enzim performansının düşmesinden kaynaklandığını göstermiştir. Üstelik düşük malat içeriği bakteroidal solunum için substrat eksiliğine yol açmış bunun sonucunda nitrogenaz aktivitesi azalma göstermiştir (Soussi et al., 1999).

Tuz stresi koşullarında azot fiksasyonundaki azalma genellikle nodül solunumunda düşüş ile ilişkilendirilmiştir. Tuza toleranslı bitkilerde nodüller içerisindeki çözünebilir şeker içeriğinin arttığı gözlenmiştir. Tuzlu koşullara toleranslı bitkilerin daha iyi performans göstermeleri, fotosentez aktivitesini koruma ve yüksek sakkarolitik aktivitesini devam ettirme ile ilişkili olduğu vurgulanmıştır. Bazı baklagiller (Vicia faba, Phaseolus vulgaris ve Glycine max) Pisum sativum'a göre tuza daha toleranslıdır. Ayrıca baklagiller, baklagil-Rhizobium birlikteliğinde ve nodül oluşumunda tuz veya osmotik strese Rhizobium bakterilerine göre daha duyarlıdırlar. Tuz stresi Rhizobium-Baklagil birlikteliğinin ilk aşamasını engellemektedir. Örneğin Bradyrhizobium japonicum ile aşılanan soya bitkilerinde $170 \mathrm{mM} \mathrm{NaCl}$ varlığında kök tüylerinin daha az kıvrılma veya deformasyon gösterdiği, $210 \mathrm{mM} \mathrm{NaCl}$ 'de ise tamamen engellendiği gözlenmiştir. (Tu 1981). Tuz stresi, azot fiksasyon aktivitesinde azalma, nodüldeki solunumun sitosolik protein üretimi özellikle süperoksit dismutaz (SOD), dehidroaskorbat redüktaz (DR) ve peroksidaz, simbiyozom membranının bütünlüğünü ve bundan dolayı leghemoglobin içeriğini olumsuz yönde etkilemiştir. Baklagillerde azot fiksasyonu üzerine tuz stresinin etkisi sürgünde $\mathrm{N}$ içeriği ve kuru ağırlıktaki tuza dayalı azalma ile ilişkilidir. Fotosentez aktivitesindeki azalma tuz stresi koşullarında baklagillerde azot fiksasyonunu etkilemiştir. Örneğin tuzlu koşullara toleranslı Rhizobium ırkları soya ile etkin bir azot fiksasyon birlikteliği kurmuştur (ElSheikh and Wood 1995). Tuza toleranslı Rhizobium ırkları orta derecede tuzlu topraklarda baklagiller ile nodül oluşturmuş ve etkili azot fiksasyonu için simbiyotik ilişki ortaya çıkmıştır. Bu nedenle tuza toleranslı Rhizobium ırklarının çeşitli baklagiller ile inokulasyonu tuzlu ortamlarda azot fiksasyonunu iyileştirmiştir (Zahran 1999).

Toplam çözünebilir şekerlerdeki artış çoğunlukla osmoregülatör oluşumlarla ilişkili olarak, osmoregulantların birikimi, koruma stratejisi yerine tuz tarafından meydana gelen hasarın bir sonucu olarak ortaya çıkmıştır. Nodül işlevinde tuz etkisi yanında iyon birikimi de (çoğunlukla $\mathrm{Na}^{+}$ve $\mathrm{Cl}^{-}$) sitotoksisiteyi ortaya çıkarmıştır. İyonlar vakuollerde depolanmadıkları sürece, hücresel bileşenlerin zarar 
Yavaş ve Ünay, Baklagillerde Kök, Nodül Oluşumu ve Azot Fiksasyonu Üzerine Bazı Küresel İklim Değişikliği Parametrelerinin Etkisi

görmesine, enzimatik aktivitelerin bozulmasına ve fazla miktarda ROS üretimine neden olmuştur. Ayrıca oksidatif stres artan tuzluluk koşullarında nodüllerin performansını azalttığı gözlenmiştir (Aranjuelo et al., 2014).

Hanumantha Rao et al. (2016)'nın yaptığı bir araştırmada; tuzluluğun nohut, börülce ve maş fasulyesinde nodüllerin azot fiksasyon etkinliğini, nodül ağırlığını ve sayısını azalttığı gözlenmiştir. Geri dönüşümü olmayan oksidayon nedeniyle nodüllerin yaşlanmasına bağlı olarak leghemoglobin içeriğinde önemli düşüşler ortaya çıkmıştır. Nodül oluşumu 6 $\mathrm{dSm}^{-1}$ tuz koşullarında gözlenmesine rağmen azot fiksasyonu tamamen engellenmiştir.

Tuzlu koşullar Rhizobiumların hayatta kalmasını ve çoğalmasını olumsuz yönde etkilemektedir. Infeksiyon iplikçiği oluşumu engellenmekte ve doğrudan kök nodül fonksiyonuna etki etmektedir. Stres koşullarının ortadan kalkması ile birlikte nodül oluşumu hızlı bir şekilde eski haline dönmektedir Baklagillerin çoğu tuz oranı yüksek topraklara hassasiyetleri nedeniyle zayıf bir şekilde nodül oluşturmaktadır. Tuzun azot fiksasyonu üzerindeki negatif etkisi, nodüllere fosfat ve solunum sübstratlarının sağlanmasının azalması ve oksijen difüzyon bariyerindeki değişikliklerden kaynaklanmıştır (van Hoorn et al., 2001; Niste et al., 2014).

Azot fiksasyonundaki azalma, nitrogenaz aktivitesi üzerinde doğrudan, leghemoglobin içeriği, solunum oranı, nodüldeki malat ve fosfat içeriğinde azalmaya yol açarak dolaylı olarak etkide bulunmaktadır. Tuzluluk nodüllerdeki oksijen difüzyon direncini artırmakta ve yapılarını değiştirmektedir. Tuzlu koşullar altında azot fiksasyonunda azalma, katalaz, askorbat peroksidaz gibi $\mathrm{H}_{2} \mathrm{O}_{2}$ süpürme enzimleri aktivitesi ile askorbik asit gibi antioksidanların seviyesindeki azalma ile paralellik göstermektedir. Nodüller tuzlu koşullar altında prolin, şekerler (pinnitol) ve laktik asit gibi çözeltiler biriktirerek, tuzlu koşullar altında ozmoregülasyonun üstesinden gelmiş gibi görünmektedir. Tuzluluğun nodül fonksiyonları üzerinde olumsuz etkilerinin şiddeti bitki türüne, Rhizobium ırkına, tuzlu koşullara maruz kalma süresine, çevre koşullarına ve tuz konsantrasyonuna bağlı olarak değişmektedir (Swaraj and Bishnoi 1999). Bitki nodüllerindeki azot fiksasyonu tuzluluğa bitki büyümesinden daha hassastır. Nodül oluşumu ve işlevi tüm bitki gelişim dönemlerinde tuzluluktan olumsuz etkilenmektedir (Bruning et al., 2015). Tuzlu koşulların asetilen redüksiyon aktivitesi üzerindeki olumsuz etkisi sürgünlerdeki azot içeriği ve kuru ağırlıktaki tuza dayalı azalma ile doğrudan ilişkilidir (Cordovilla et al., 1995). Maş fasulyesi genotipleri tuzlu koşullara maruz kaldığında nodüllerin nisbi nem içeriğinin azaldığı bildirilmiştir (Manchanda and Garg 2008). Fasulye bitkisi $\mathrm{NaCl}^{\prime}$ e maruz kaldığında nodüllerde yüksek oranda $\mathrm{Na}^{+}$ve $\mathrm{Cl}^{-}$gözlenmiştir (Ashraf and Bashir 2003). Bolanos et al. (2006) da tuzlu koşullarda bezelye köklerindeki nodüllerde demir içeriğinin şiddetli bir şekilde azaldığını saptamışlardır. Tuzluluk kök tüyü gelişimini engellemek ve bitki başına nodül sayısını azaltmak suretiyle infeksiyon oluşumunu ve nodül birim ağırlığı başına azot fiksasyon miktarını etkilemiştir (Manchanda and Garg 2008). Tejera et al. (2005) tuzlu koşullarda fasulye bitkilerinde azalan azot fiksasyon parametrelerinin azot fiksasyonunun bir göstergesi olan asetilen redüksiyon aktivitesi ve nodül sayısında azalma şeklinde tepki verdiğini vurgulamışlardır. Tuzlu koşullara maruz kalan bezelye, bakla, fasulye ve soya gibi bazı baklagil bitkilerinde hem azot fiksasyonu hem nodül solunumu belirgin bir şekilde engellenmiş ve bu nedenle dolaylı olarak leghemoglobin içeriği ve solunum azalmıştır (Swaraj and Bishnoi 1999).

\section{$\mathrm{CO}_{2}$ artışı}

Fotosentez, transpirasyon ve biyomas üretimi $\mathrm{CO}_{2}$ değişimine oldukça hassastır. Artan $\mathrm{CO}_{2}$ koşulları, ekosistem fonksiyonlarını ve tarımsal verimi etkilemektedir. Bitki C:N dengesi burada büyük önem taşımaktadır. Azot, bitki büyümesi ve tohum üretimini sınırlayan en önemli faktörlerden birisidir. Bu nedenle artan $\mathrm{CO}_{2}$ nedeniyle karbon varlığındaki artış, azot eksikliğini artırmakta ve bitkideki azot içeriğinde azalmaya neden olmaktadır (Hikosaka et al., 2011).

$\mathrm{CO}_{2}$ artışı, dokulardaki $\mathrm{N}$ içeriğini azaltmakta, $\mathrm{N}$ eksikliği belirtileri hızlanmakta fakat bitki biyomas üretimini etkilememektedir. Özellikle nodüllerde $\mathrm{CO}_{2}$ artışı, nodül gelişimi için hayati fonksiyonlar ile malonat için önemli bir karbon kaynağı olan malat birikimini artırmaktadır. Artan $\mathrm{CO}_{2}$ koşullarında daha yüksek fotosentetik asimilasyon oranları, kök ve sürgün biyoması gözlenmektedir. Bu artış ya kök gelişiminin teşviki ya da kök salgı oranının daha yüksek olmasından kaynaklanmaktadır. $\mathrm{CO}_{2}$ artışı ile kök salgılarındaki artış, rizosferdeki mikrobiyal gelişimi ve aktiviteyi teşvik edebilmektedir (Haase et al., 2007).

$\mathrm{CO}_{2}$ 'in arttığı koşullarda azot fiksasyonundaki artış nodül boyutunda, nodül sayısında ve nitrogenaz aktivitesinde artışla sonuçlanmaktadır. Büyük nodül kütlesine sahip baklagil türleri artan $\mathrm{CO}_{2}$ koşullarına daha şiddetli tepki vermektedirler (Rogers et al., 2009; Cernusak et al., 2011).

Yapılan araştırmalarda; $\mathrm{CO}_{2}$ artışına maruz kalan yonca ve bezelye bitkilerinde nodül $C$ etkinliğinin (daha fazla kuru madde ve karbonhidrat içeriği) arttığı 
Yavaş ve Ünay, Baklagillerde Kök, Nodül Oluşumu ve Azot Fiksasyonu Üzerine Bazı Küresel İklim Değişikliği Parametrelerinin Etkisi

ancak bu artışın toprak üstü aksamdaki karbonhidrat artışına yansımadığı saptanmıştır (Rogers et al., 2009; Cernusak et al., 2011). Karbondioksit artışına (700 mol

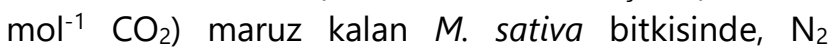
fiksasyonunda artış olmasına rağmen, daha fazla fotoasimilat oluşumunun nodül $\mathrm{N}_{2}$ fiksasyonundaki artışa etki etmediği gözlenmiştir. Üstelik $\mathrm{CO}_{2}$ artışına maruz kalan bitkilerin nodüllerinde karbonhidrat içeriğinin azaldığı ortaya çıkmıştır (Aranjuelo et al., 2014).

Baklagil bitkilerinin $\mathrm{CO}_{2}$ artışına tepkisi çevresel koşullara, bitki türlerine ve bakteri ırkına bağlı olarak değişmektedir. Örneğin; yüksek $\mathrm{CO}_{2}$ koşullarında, Pisum sativum bitkisinde protein ve serbest amino asit içeriğinde bir düşüş gözlenmesine rağmen, nodüllerdeki amino asit içeriğinde bir değişim olmadığı ortaya çıkmıştır. $\mathrm{CO}_{2}$ artışına maruz kalan bezelye bitkisinde 3 hafta sonra $\mathrm{N}_{2}$ fiksasyonunun artığı da görülmüştür (Aranjuelo et al., 2014). CO2'nin 2 katına çıkması, soyada BNF'da önemli artışlara neden olmuştur. İki hafta yüksek $\mathrm{CO}_{2}$ miktarına maruz kalma soya bitkisinde nitrogenaz aktivitesini, nodül kütlesini ve sayısını artırmakta iken, 48 saat gibi kısa süre $\mathrm{CO}_{2}{ }^{\prime} \mathrm{e}$ maruz kalmanın hiçbir etkisi gözlenmemiştir. (Finn and Brun 1982). Bezelyede yapılan bir çalışmada; uzun süreli $\mathrm{CO}_{2}$ artışının, nodül gelişimini artırarak azot fiksasyonunu teşvik ettiği, kısa süreli $\mathrm{CO}_{2}$ artışlarının ise nodül fonksiyonunun etkileyerek azot fiksasyonunu arttırdığı bulunmuştur (Phillips et al., 1976). Ayrıca fasulyede yüksek $\mathrm{CO}_{2}$ miktarına maruz kalmanın nitrogenaz aktivitesini arttırdığı bildirilmiştir (Ortega et al., 1992). Artan $\mathrm{CO}_{2}$ miktarı soyada kök kütlesi, kök gelişimini ve dağılımını etkilerken (Prasad et al., 2005), yüksek toprak sıcaklıkları yerfıstığında kök/sürgün oranını, kök gelişimini, nodül ağırlığını ve nodül sayısını önemli bir şekilde düşürmüştür (Prasad et al., 2000). Üstelik nodül sayısı ve nodül kuru ağırlığındaki düşüşler, yüksek toprak sıcaklıklarında yüksek hava sıcaklıklarına nazaran daha hassastır (Prasad et al., 2001)

$\mathrm{CO}_{2}$ artışına maruz kalma toplam kök kuru madde ağırlığını, kök hacmini ve kök uzunluğunu artırmıştır. Ayrıca merkezi silindirin çapında ve korteksin genişliğindeki artışlar nedeniyle de kök anatomisinde önemli değişiklikler meydana gelmiştir. Fakat $\mathrm{CO}_{2}$ zenginleştirmesinin toplam kök sayısı ya da belirli derinlikteki kök sayısı üzerine etkisinin olmadığı gözlenmiştir (Reddy et al., 1997). Baklagillerde $\mathrm{CO}_{2}$ artışının direkt etkisi kök büyümesi ve kütlesindeki artış, nodülasyon, mikrobiyal aktivite ve dolayısıyla BNF üzerine olmuştur. Artan $\mathrm{CO}_{2}$ koşullarında artan fotosentetik karbon fiksasyonu, mikrobiyal aktivite için daha fazla enerji sağlamış ve baklagillerde azot fiksasyonunu kolaylaştırmıştır. Baklagiller ve bakteriler arasındaki simbiyotik ilişki artan $\mathrm{CO}_{2}$ koşullarında daha fazladır. $\mathrm{CO}_{2}$ konsantrasyonundaki artış nodül gelişimini (nodül kuru ağırlığı ve nodül sayısı) ve nodül fiksasyonunu (nitrogenaz aktivitesi, azot fiksasyonu ve tüm bitki azot içeriği) artırmıştır (Prasad et al., 2005).

\section{SONUÇ}

İklim değişikliği tane baklagillerde kök gelişimini, nodül oluşumunu ve azot fiksasyonunu önemli derecede etkilemektedir. $\mathrm{CO}_{2}{ }^{\prime}$ in arttığı koşullarda azot fiksasyonundaki artış nodül çapında, sayısında ve nitrogenaz enzim aktivitesinde artışla sonuçlanmaktadır. Tane baklagiller tüm gelişim dönemlerinde özellikle generatif dönemde hem düşük hem yüksek sıcaklıklara oldukça duyarlıdır. Kurak koşullar ise baklagillerde nodül sayısını, çapını, infeksiyon iplikçiği oluşumunu önemli bir şekilde azaltmaktadır. Baklagiller ayrıca tuzluluğa da oldukça hassas bitkilerdir. Tuzlu koşullar altında baklagil bitkilerinde kök tüyü infeksiyonu engellenmekte, nodül sayısı, azot fiksasyonu, nodül solunumu ve leghemoglobin içeriği azalmaktadır.

\section{KAYNAKLAR}

Aranjueloa I., Arrese-Igorb C and Moleroc G., 2014. Nodule performance within a changing environmental context. Journal of Plant Physiology, 171: 1076-1090.

Ashraf M and Bashir A., 2003. Salt stress induced changes in some organic metabolites and ionic relations in nodules and other plant parts of two crop legumes differing in salt tolerance. Flora, 198: 486-98.

Ashraf M and Iram A., 2005. Drought stress induced changes in some organic substances in nodules and other plant parts of two potential legumes differing in salt tolerance. Flora, 200: 535-546.

Bhandari K., Dev Sharma K., Hanumantha Rao B., Siddique KHM., Gaur P., Agrawal SK., Nair RM and Nayyar H., 2017. Temperature sensitivity of food legumes: a physiological insight. Acta Physiologiae Plantarum, 39: 68.

Bolaños L., Martín M, El-Hamdaoui A., Rivilla R and Bonilla I., 2006. Nitrogenase inhibition in nodules from pea plants grown under salt stress occurs at the physiological level and can be alleviated by B and Ca. Plant and Soil, 280: 135-142.

Bruning B., van Logtestijn R., Broekman R., de Vos A., Gonza'lez AP and Rozema J., 2015. Growth and nitrogen fixation of legumes at increased salinity under field conditions: Implications for the use of green manures in saline environments. AoB Plants, 7: 1-8.

Cernusak LA., Winter K., Martinez C., Correa E., Aranda J., Garcia M., Jaramillo C and Turner BL., 2011. Responses of legume versus nonlegume tropical tree seedlings to 
Yavaş ve Ünay, Baklagillerde Kök, Nodül Oluşumu ve Azot Fiksasyonu Üzerine Bazı Küresel İklim Değişikliği Parametrelerinin Etkisi

elevated $\mathrm{CO}_{2}$ concentration. Plant Physiology, 157: 372385.

Cordovilla MP., Ligero F and Lluch C., 1995. Influence of host genotypes on growth, symbiotic performance and nitrogen assimilation in faba bean (Vicia faba L.) under salt stress. Plant and Soil, 172: 289-297.

Dart PJ., Islam R and Eaglesham A., 1975. The root nodule symbiosis of chickpea and pigeonpea. In Proceedings, International Workshop in Grain Legumes, 13-16 January, ICRISAT, Patancheru, India, pp. 63-83.

De Silva M., Purcell LC and King CA., 1996. Soybean petiole ureide response to water deficits and decreased transpiration. Crop Science, 36: 611-616.

El-Sheikh EAE and Wood M., 1995. Nodulation and $\mathrm{N}_{2}$ fixation by soybean inoculated with salt-tolerant rhizobia or salt-sensitive bradyrhizobia in saline soil. Soil Biology and Biochemistry, 27: 657-661.

Farooq M., Gogoi N., Barthakur S., Baroowa B., Bharadwaj N., Alghamdi SS and Siddique KHM., 2016. Drought stress in grain legumes during reproduction and grain filling. Journal of Agronomy and Crop Science, 203: 81 102.

Feller U., 2016. Drought stress and carbon assimilation in a warming climate: reversible and irreversible impacts. Journal of Plant Physiology, 203: 84-94.

Finn GA and Brun WA., 1982. Effects of atmospheric $\mathrm{CO}_{2}$ enrichment on growth, nonstructural carbohydrate content and root nodule activity in soybean. Plant Physiology, 69: 327-331.

Garg N and Singla R., 2004. Growth, photosynthesis, nodule nitrogen and carbon fixation in the chickpea cultivars under salt stress. Brazilian Journal of Plant Physiology, 16(3): 137-146.

Gaur PM., Samineni S., Krishnamurthy L., Kumar S., Gha nem ME and Beebe S., 2015. High temperature tolerance in grain legumes. Legume Perspect, 7: 6-7.

Graham PH and Vance CP., 2003. Legumes: importance and constraints to greater use. Plant Physiology, 131: 872877.

Haase S., Neumann G., Kania A., Kuzyakov Y., Römheld V and Kandeler E., 2007. Elevation of atmospheric $\mathrm{CO}_{2}$ and $\mathrm{N}$ nutritional status modify nodulation, nodule-carbon supply, and root exudation of Phaseolus vulgaris L. Soil Biology and Biochemistry, 39: 2208-2221.

Hanumantha Rao B., Nair RM and Nayyar H., 2016. Salinity and High Temperature Tolerance in Mungbean (Vigna radiata (L.) Wilczek) from a Physiological Perspective. Frontiers in Plant Science, 7: 957.

Hikosaka K., Kinugasa T., Oikawa S., Onoda Y and Hirose T., 2011. Effects of elevated $\mathrm{CO}_{2}$ concentration on seed production in $\mathrm{C}_{3}$ annual plants. Journal of Experimental Botany, 62: 1523-1530.
Huang $J$ and Redman RE., 1995. Solute to salinity and calcium supply in cultivated and wild barley. Journal of Plant Nutrition, 18: 1371-1389.

Hungria M., Franco AA and Sprent JJ., 1993. New sources of high temperature tolerant rhizobia for Phaseolus vulgaris L. Plant and Soil, 149: 103-109.

IPCC 2013. Summary for Policymakers Climate Change 2013: The Physical Science Basis Contribution of Working Group I to the Fifth Assessment Report of the Intergovernmental Panel on Climate Change (Eds. Stocker D., Qin GK., Plattner MMB., Tignor SK., Allen J., Boschung A., Nauels Y., Xia VB and Midgley PM). Cambridge University Press. pp. 5-9.

Kunert KJ., Vorster BJ., Fenta BA., Kibido T., Dionisio G and Foyer $\mathrm{CH}$., 2016. Drought stress responses in soybean roots and nodules. Frontiers Plant Science, 7: 17.

Manchanda G and Garg N., 2008. Salinity and its effects on the functional biology of legumes. Acta Physiologiae Plantarum, 30: 595-618.

Minchin FR., Summerfield RJ., Hadley P and Roberts EH., 1980. Growth, longevity and nodulation of roots in relation to seed yield in chickpea (Cicer arietinum L.). Experimental Agriculture, 16: 241-261.

Niste M., Vidican R., Rotar I., Stoian VR and Pop Miclea R., 2014. Plant nutrition affected by soil salinity and response of rhizobium regarding the nutrients accumulation. Journal of ProEnvironment, 7: 71-75.

Ortega JL., Sanchez F., Soberon M and Flores ML., 1992. Regulation of nodule glutamine-synthetase by $\mathrm{CO}_{2}$ levels in bean (Phaseolus vulgaris L.). Plant Physiology, 98: 584-587.

Phillips DA., Newell KD., Hassell SA and Felling CE., 1976. The effect of $\mathrm{CO}_{2}$ enrichment on root nodule development and symbiotic N2 reduction in Pisum sativum $\mathrm{L}$. American Journal of Botany, 63: 356-362.

Popelka JC., Terryn N and Higgins TJV., 2004. Gene technology for grain legumes: can it contribute to the food challenge in developing countries? Plant Science, 167: 195-206.

Prasad PVV., Craufurd PQ and Summerfield RJ., 2000. Effect of high air and soil temperature on dry matter production, pod yield and yield components of groundnut. Plant and Soil, 222: 231-239.

Prasad PVV., Craufurd PQ., Kakani VG., Wheeler TR and Boote KJ., 2001. Influence of high temperature during pre- and post-anthesis stages of floral development on fruit-set and pollen germination in peanut. Australian Journal of Plant Physiology, 28: 233-240.

Prasad PVV., Allen Jr., LH and Boote KJ., 2005. Crop Responses to elevated carbon dioxide and interaction with temperature: Grain legumes. Journal of Crop Improvement, 13(1/2): 113-155. 
Yavaş ve Ünay, Baklagillerde Kök, Nodül Oluşumu ve Azot Fiksasyonu Üzerine Bazı Küresel İklim Değişikliği Parametrelerinin Etkisi

Rawsthorne S., Hadley P., Roberts EH and Summerfield RJ., 1985. Effects of supplemental nitrate and thermal regime on the nitrogen nutrition of chickpea (Cicer arietinum L.) II: Symbiotic development and nitrogen assimilation. Plant and Soil, 83: 279-293.

Reddy KR., Hodges HF and McKinion JM., 1997. Crop modeling and applications: a cotton example. Advances in Agronomy, 59: 225-290.
Rogers A., Ainsworth EA and Leakey AD., 2009. Will elevated carbon dioxide concentration amplify the benefits of nitrogen fixation in legumes?. Plant Physiology, 151: 1009-1016.

Rupela OP and Saxena MC., 1987. Nodulation and nitrogen fixation. The Chickpea (Eds. Saxena MC and Singh KB). CAB International, pp. 191-206. 